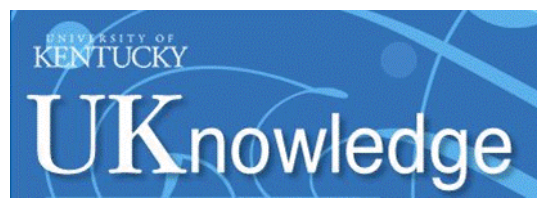

University of Kentucky

UKnowledge

Theses and Dissertations--Art and Visual Studies

Art and Visual Studies

2011

\title{
THE ART OF NOTHINGNESS: DADA, TAOISM, AND ZEN
}

Erin Megan Lochmann

University of Kentucky, erinlochmann@gmail.com

Right click to open a feedback form in a new tab to let us know how this document benefits you.

\section{Recommended Citation}

Lochmann, Erin Megan, "THE ART OF NOTHINGNESS: DADA, TAOISM, AND ZEN" (2011). Theses and Dissertations--Art and Visual Studies. 1.

https://uknowledge.uky.edu/art_etds/1

This Master's Thesis is brought to you for free and open access by the Art and Visual Studies at UKnowledge. It has been accepted for inclusion in Theses and Dissertations--Art and Visual Studies by an authorized administrator of UKnowledge. For more information, please contact UKnowledge@lsv.uky.edu. 


\section{STUDENT AGREEMENT:}

I represent that my thesis or dissertation and abstract are my original work. Proper attribution has been given to all outside sources. I understand that I am solely responsible for obtaining any needed copyright permissions. I have obtained and attached hereto needed written permission statements(s) from the owner(s) of each third-party copyrighted matter to be included in my work, allowing electronic distribution (if such use is not permitted by the fair use doctrine).

I hereby grant to The University of Kentucky and its agents the non-exclusive license to archive and make accessible my work in whole or in part in all forms of media, now or hereafter known. I agree that the document mentioned above may be made available immediately for worldwide access unless a preapproved embargo applies.

I retain all other ownership rights to the copyright of my work. I also retain the right to use in future works (such as articles or books) all or part of my work. I understand that I am free to register the copyright to my work.

\section{REVIEW, APPROVAL AND ACCEPTANCE}

The document mentioned above has been reviewed and accepted by the student's advisor, on behalf of the advisory committee, and by the Director of Graduate Studies (DGS), on behalf of the program; we verify that this is the final, approved version of the student's dissertation including all changes required by the advisory committee. The undersigned agree to abide by the statements above.

Erin Megan Lochmann, Student

Dr. Anna Brzyski, Major Professor

Prof. Doreen Maloney, Director of Graduate Studies 


\section{THE ART OF NOTHINGNESS: \\ DADA, TAOISM, AND ZEN}

\section{THESIS}

A thesis submitted in partial fulfillment of the requirements for the degree of Masters of Art in the

College of Fine Arts

at the University of Kentucky

By

Erin Megan Lochmann

Lexington, Kentucky

Director: Dr. Anna Brzyski, Associate Professor of Art History

Lexington, Kentucky

2011

Copyright (C) Erin Megan Lochmann 2011 


\title{
ABSTRACT OF THESIS
}

\section{THE ART OF NOTHINGNESS: \\ DADA, TAOISM, AND ZEN}

\begin{abstract}
When examining the art, actions, and writings of Zurich Dadaists it becomes apparent that there is an affinity with Eastern thought, namely Taoism and Zen Buddhism. It cannot be said that Eastern thought directly influenced the artistic production of these Dadaists. However, the philosophy of Dada artists in Zurich mirrors that of Taoism and Zen so strongly that this connection cannot be ignored, although the Western art historical cannon has done just that. Exploring this connection offers a new perspective of Zurich Dada and encourages a reconsideration of the commonly applied label of nihilism to this group of Dadaists.
\end{abstract}

KEYWORDS: Zurich Dada, Taoism, Buddhism, Nihilism, the Unknown

Erin Megan Lochmann

December 9, 2011 


\section{THE ART OF NOTHINGNESS:}

DADA, TAOISM, AND ZEN

By

Erin Megan Lochmann

Dr. Anna Brzyski

Director of Thesis

Prof. Doreen Maloney

Director of Graduate Studies

December 9, 2011 


\section{TABLE OF CONTENTS}

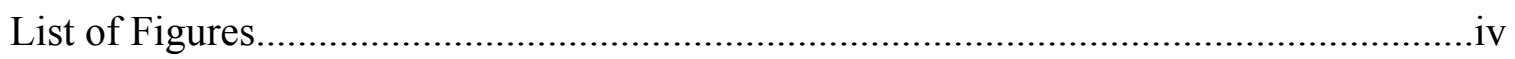

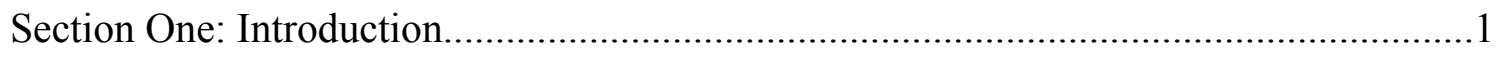

Section Two: The West's Approach to Eastern Philosophies..............................................

Section Three: A Comparison of Zurich Dada and Eastern Philosophies.........................20

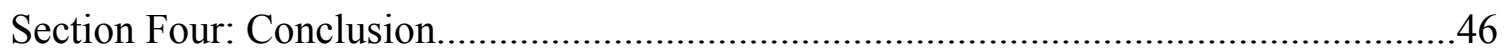

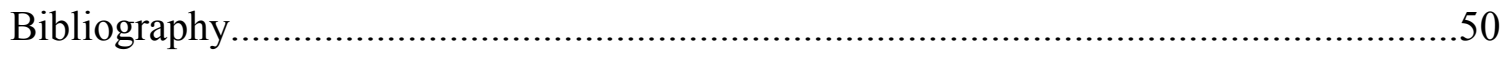

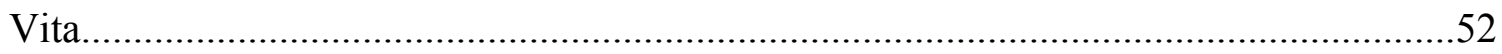




\section{LIST OF FIGURES}

Figure 3.1, Marcel Janco, Untitled (Mask for Firdusi), 1917-1918..................40

Figure 3.2, Marcel Janco, Untitled (Mask, Portrait of Tzara), 1919...................40

Figure 3.3, Marcel Janco, Illustration of the cover of the journal Dada, no. 3, Tristan Tzara editor, Mouvement Dada, 1918..............................41

Figure 3.4, Hans Richter, Rhythmus 21 (Rhythm 21), ca. 1921......................41

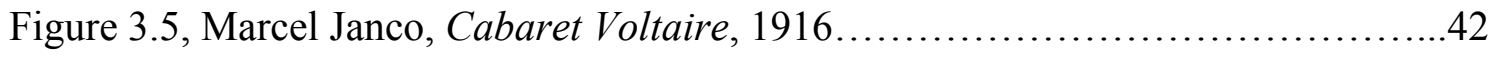

Figure 3.6, Hugo Ball in "cubist costume" reciting his poem Elefantenkarawane, at the

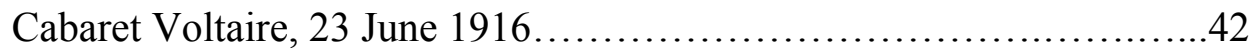

Figure 3.7, Hugo Ball, Karawane. Sound poem in Dada Almanach, 1920, p.53........43

Figure 3.8, Tristan Tzara, L'amiral cherche une maison à louer, as published in the

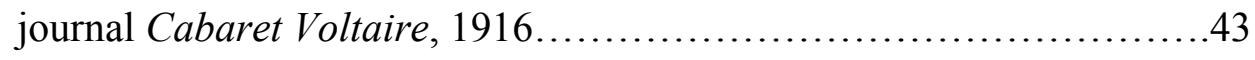

Figure 3.9, Hans Arp, Untitled (Collage with Square Arranged According to the Laws of

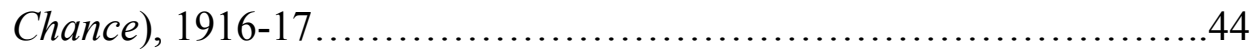

Figure 3.10, Hans Arp, Untitled (Rectangles According to the Laws of Chance), 1916..44 Figure 3.11, Hans Arp, Untitled (Automatic Drawing), 1917-18 (inscribed 1916)......45 
Section One: Introduction

One of the first references to Dada in Japan appeared in 1920 in the Tokyo newspaper, Yorozu Chōhō. There were two articles about the movement, which discussed its goals and ideas and included reproductions and images of Dada art. The first article appeared in June and a second one in August. The second article was broken up into two sections. The author of the first section, Shiran Wakatsuki, spoke of an association between of Dada and Buddhism by discussing the meaning of the word Dada. He observed that, "The word's present meaning in art was...the same as the word 'Mu' (nothingness) which he did not consider a new concept. It had been discussed repeatedly in Buddhism and by Nietzsche." ${ }^{\text {T }}$ This association with the notion of nothingness, of a void or lack, should not be understood as a nihilistic tendency and is an obvious feature of Dada that will be explored throughout this paper.

Another person who saw a correlation between Dada and Buddhism was a Japanese Dada poet, Takahashi Shinkichi. He found this relationship especially prevalent in the writings of Tristan Tzara. In Buddhist Elements in Dada: A Comparison of Tristan Tzara, Takahashi Shinkichi, and Their Fellow Poets, the author Ko Won reflected on Takahashi's understanding of Tzara and his art. Won states,

...[Takahashi] quotes a line from Tzara's Dada Manifetso 1918, "Dada means nothing," which both recollects his own Dada period and observes Tzara as follows: “...It cannot be doubted that Buddhism was absorbed promptly into the sagacious brain of Tzara, a young Rumanian who studied philosophy. His Buddhist background must have been Zen, because his denial of verbal activity — by saying 'thought without words' or 'no count on

\footnotetext{
${ }^{1}$ Toshiharu Omuka, "Tada=Dada (Devotedly Dada) for the Stage: The Japanese Dada Movement," in The Eastern Dada Orbit: Russia, Georgia, Ukraine, Central Europe and Japan, ed. Stephen C. Foster (New York: G.K. Hall \& Co., 1998), 223-310.
} 
words'-is in common with Zen principle of no-word.",2

Although it is difficult or impossible to confirm with certainty that Tzara had any specific education in Zen or was an actual practitioner of Buddhism, it is clear that Japanese observers assumed that he was aware of Buddhism and Taoism. Won acknowledged this when discussing Takahashi's essay The Revival of Dada. He writes: “...Takahashi refers to Tzara's words from his lecture of 1922: 'Dada is not at all modern. It is more in the nature of a return to an almost Buddhist religion of indifference'..."3 Won continues linking Tzara to Eastern thought following Takahashi's example:

In addition to Tzara's brief mention of Buddhism in 1922, it is interesting that he also refers to Taoist philosophy in the same lecture: “...Chouang-Dsi was just as Dada as we are. You are mistaken if you take Dada for a modern school, or even for a reaction against the school of today." The Chinese name Chouang-Dsi is no doubt that of Chuang Tzŭ (i.e., Chuang Chou, c. 369-c. 286 B.C.), whose philosophy idealizes the state of nature or naturalness ( $t z \breve{u}$-jên) in favor of anarchic individualism as opposed to artificiality, conventions, and institutions, the whole idea leading to a denial of the results of "culture," that is, civilization. ${ }^{4}$

Dada, Taoism, and Buddhism do not equate indifference with moral apathy, and the denial of the results of culture is not an endorsement of absolute chaos.

In this instance, the rejection of civilization does not require the destruction of physical objects or tearing down of governments and social institutions through riots and rebellion. Rather, it is a call to look beyond the artificial constrictions of society in order to gain an unobstructed view of existence. Once this perspective is achieved, one is able

\footnotetext{
${ }^{2}$ Ko Won, Buddhist Elements in Dada: A Comparison of Tristan Tzara, Takahashi Shinkichi, and Their Fellow Poets (New York: NYU Press, 1977), 87.

${ }^{3}$ Ibid., 84.

${ }^{4}$ Ibid., 85.
} 
to recognize the connectedness of reality, valuing all aspects of life without assigning moral stigmas. This indifference is actually an enlightened view of reality. Tzara recognized that this aspect of Dada philosophy shared a great deal with ancient Eastern philosophy and publicly called attention to this correlation.

Clearly, there is no admission of influence by Tzara but he recognized the striking similarities between Dada, Taoism, and Buddhism. The conceptual parallels maybe circumstantial but, as will be shown, they are so strong they cannot be denied. Japanese writers and artists have noted similarities and links between Dada, Taoism, and Buddhism. However, these connections have not attracted significant attention in the standard Western monographs on Dada. Intellectuals in Japan were explicit about the parallels that struck them, but Europe has not been. This omission raises the question of why the influence of ideas from the Eastern part of the world on Dada philosophy and art has been largely ignored.

Within the Western art historical cannon, Dada is often described as an art movement that eludes definition. Leah Dickerman, author of the 2005 survey Dada published by the National Gallery of Art, states that Dada “...cannot be understood as a movement in the traditional sense of a small alliance of artists, working and showing together, committed to a common aesthetic credo and style." ${ }^{, 5}$ As an international movement, Dada artists were located in various major cities: Zurich, Paris, Berlin, Hannover, Cologne, and New York. What is implicit in the breakdown of Dada into different countries and cities is the notion that there were multiple manifestations of the Dada philosophy and differences in focus of each artist or group in their respective cities

\footnotetext{
${ }^{5}$ Leah Dickerman, Dada (New York: National Gallery of Art, Washington, 2005), 1.
} 
vary. These artists were linked more by their approach to art making, which amounted to “...a set of strategies - abstraction, collage, montage, the readymade, the incorporation of chance and forms of automatization..."6

Although there is an undercurrent of humor and whimsy in Dada, it is also generally described in terms of negation. Negative terms and descriptions, such as antiart, rejection of tradition and logic, "subversions of cultural forms of social authority,"7 anarchism, and nihilism, are applied to Dada artists, their creations, and activities. While most of these terms are applicable to varying degrees, I will argue that the terms anarchism and nihilism mischaracterize the Dada artists in Zurich. A direct comparison of the ideas and actions of the Zurich Dada group with those of Taoism and Zen Buddhism will not only reveal obvious connections between Zurich Dada and those of Eastern philosophies, but will also help to problematize the common association of this group of Dada artists with nihilism and anarchism. Since the focus of this paper is solely on the art and activities of the Zurich Dadaists, declarations made do not necessarily reflect the endeavors of Dada artists in other cities. Artists included in this discussion are Rumanians Tristan Tzara and Marcel Janco along with Hugo Ball, Hans Arp, Richard Hülsenbeck, and Hans Richter, all from Germany.

An investigation by Western scholars into the relationship that Dada and Eastern thought share has not been developed in depth. Certain authors have commented on or documented references to Buddhism and Taoism by Dada artists, as will be seen in section two of this paper, but these separate accounts have not been employed as a resource for changing the way in which Dada is portrayed within the field of art history.

\footnotetext{
${ }^{6}$ Ibid., 7.

${ }^{7}$ Dickerman, 11 .
} 
Richard Sheppard provides ample evidence of Dada's connection to Eastern thought in his book Modernism—Dada—Postmodernism ${ }^{8}$, but he does not provide an in-depth analysis of the phenomenon. Instead, he implies that this connection is unimportant to an understanding or discussion of Dada. In his almost four hundred page book, one small chapter is devoted to the connection between Dada and Taoism and Buddhism. However, this chapter is framed as Dada's association to mysticism in general and includes discussions of Christian mysticism as well. Not to mention that, as the title of the book suggests, the main interest of the author is a consideration of Dada in relation to modernism and postmodernism.

Sheppard even references other authors' examinations of Dada and Buddhism, saying at one point "Nancy Wilson Ross connected Dada and Zen while making the very

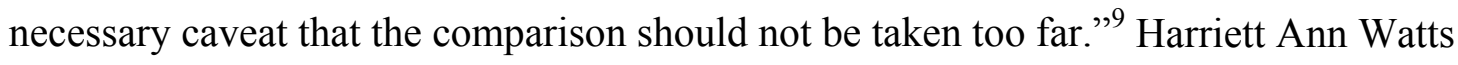
does make a direct case for a link with Eastern thought. Nonetheless, her focus is simply on the art of Hans Arp and the single notion of chance as understood in the $I$ Ching. ${ }^{10}$ The discussion does not extend any further. Author Toshiharu Omuka discusses Buddhism, as seen above, but this is simply in the context of Dada in Japan. Finally, Ko Won offers ample information for drawing comparisons between the Dada artist Tristan Tzara and Buddhism, but makes the statement very early on in his book that, "The writer must confess that his approach toward this particular area of comparison cannot advance too

\footnotetext{
${ }^{8}$ Richard Sheppard, Modernism-Dada-Postmodernism (Evanston, Illinois: Northwestern University Press, 2000).

${ }^{9}$ Sheppard, 266.

${ }^{10}$ Harriett Ann Watts, Chance: A Perspective on Dada (Ann Arbor, MI: UMI Research Press, 1980).
} 
far beyond the possibility of parallelism at this time, because no sufficient material which might prove Tzara's Buddhist background has been found."11

Due to the ephemeral nature of Dada and the noncommittal attitude of Dada artists, it is not surprising that direct, hard evidence cannot be found that definitively links Dada to Taoism or Zen. However, the various (and numerous) citations to Eastern thought by Zurich Dadaists, the already existent atmosphere of a discussion of Buddhism during their Dada activities, and correlations that can be seen between Dada, Taoism, and Zen Buddhism provide enough material to propose a serious discussion about their connection. Additionally, there was and had previously been a general interest in Eastern thought and art production in Europe, take Japonisme ${ }^{12}$ for example. I will focus my analysis on the use of language in an abnormal way that highlights its arbitrary nature, the notion that established features of the world must be dismantled for one to gain a more complete grasp on reality, a general recognition of the fluctuations of the whole of existence that encourages change yet implies oneness, and an emphasis on chance. These are all traits that Zurich Dada shares with Taoism and Zen.

It may be difficult to confirm when and how the Zurich Dada members became familiar with Taoism and Zen Buddhism. Still, an investigation of these Dadaists' artworks, writings, and actions from a perspective that takes into account forms of Eastern thought is worth considering because it presents an opportunity for a new platform of discussion that will allow a broader understanding of these artists and Dada as a whole. There are two features in particular that are common in Western discussions about Dada, Buddhism, and Taoism: nihilism and nothingness. The way in which

\footnotetext{
${ }^{11}$ Won, 12.

${ }^{12}$ A French term coined in the early 1870 s to describe the general influence of the arts of Japan on Europe. It was especially inspirational to Impressionist painters.
} 
Western scholars understand and characterize these notions in association to Dada can be altered when one views the movement in association with Eastern thought. Once their relationship is established, the groundwork for a re-conception of Dada will be possible and the notion of Zurich Dada championing nihilism, anarchy, and nothingness can be rejected. Additionally, by interpreting the artistic activities of one group of Dada artists in a new way, a discussion of Dada will hopefully be promoted that is attentive to the multifaceted nature of this artistic movement, and perhaps others movements in art history as well. 
Section Two: The West's Approach to Eastern Philosophies

By 1900 western artists shared a common interest in the art and practices of culture that were deemed "primitive" and saw in them a source for undermining the popular bourgeois art and culture of the time. These artists "...were concerned with the exciting new formal and expressive possibilities offered by Primitive art and also with the new kinds of thought that it provoked about artistic processes and the social function of art." ${ }^{, 13}$ Picasso even recalled that "Everyone always talks about the influence of the negroes on me. What can I do? We all loved fetishes. Van Gogh said: 'Japanese art, we all had that in common.' For us it was the Negroes. Their forms had no more influence on me than they had on Matisse. Or on Derain. ${ }^{.14}$ Rejecting the tenets of Western bourgeois society and art by embracing aspects of another culture appeared to be common, and Dada artists were not the only westerners that have had an interest in or connection to the East.

Additionally, a discussion of Buddhism has been present in the West in one form or another for some time before the nineteenth century. However, for the purpose of this paper, historical documentation and deliberation by westerners will only include those events that occur in the final years of the eighteenth century and the nineteenth century. Also, it is important to keep in mind Said's statement regarding the relationship between the East and West during this same time period:

Taking the late eighteenth century as a very roughly defined starting point Orientalism can be discussed and analyzed as the corporate institution for dealing with the Orient—dealing with it by making statements about it, authorizing views of it, describing it, by teaching it, settling it, ruling over it: in short, Orientalism as a

\footnotetext{
${ }^{13}$ Primitivism and Twentieth-Century Art: A Documentary History, edited by Jack Flam with Miriam Deutch (Berkeley: University of California Press, 2003), 25.

${ }^{14}$ Ibid., 33.
} 
Western style for dominating, restructuring, and having authority over the Orient. ${ }^{15}$

Much of the European discourse on Buddhism can be included under the rubric of Orientalism.

Seen from this perspective, Buddhism had to be dealt with by the colonizing West, a predominantly Christian institution that felt it had moral and cultural authority over this primitive religion and the societies that upheld it. This means that westerners' discussion of Buddhism was much less about Buddhism proper and much more about their interaction with and understanding of Buddhism. It is about making that new belief system from a different culture conform to an already established cultural system that views itself as superior, as the norm. Since Dada was part of the western tradition, it should be understood that Dada artists were not Buddhists or Taoists. They simply recognized something familiar about certain characteristics of East philosophy and used these attributes to explore, situate, and perhaps even validate their own position in and their understanding of the world. Again, it is not Buddhism proper (or Taoism proper) that the Dadaists' engaged in, but only those concepts which fit into the reality that they knew.

By considering the West to be the measure of all things, or the norm, a hierarchy is automatically created which positions non-westerners as the "other." This cultural hierarchy means that "The relationship between Occident and Orient is a relationship of power, of domination, of varying degrees of a complex hegemony..."16 Thus, aspects of the "other" culture are things to be defined and categorized by Western standards. The West is the observer and the East is the thing to be observed. It is a subject of study, not a

\footnotetext{
${ }^{15}$ Edward Said, Orientalism (New York: Vintage Books, 1979), 3.

${ }^{16}$ Ibid., 5 .
} 
different manifestation of humanity that Europeans can engage with and that both sides could prosper from.

Those elements that did not conform to the West's understanding of reality were either completely ignored or considered incorrect and redefined in European terms. Said points out, “...it needs to be made clear about cultural discourse and exchange within a culture that what is commonly circulated by it is not 'truth' but representations." 17 Moreover, western knowledge of the East came from various sources that did not provide accurate information. Regardless of whether or not this was done on purpose, misinterpretation or mischaracterization created in the minds of westerners an "East" that did not truly exist. This same misconception occurred when Europeans attempted to comprehend and explain Buddhism.

There were many highly influential western intellectuals and philosophers who participated in the investigation and discussion of Buddhism: Friedrich Schlegel, MichelJean-François Ozeray, Eugène Burnouf, Friedrich Schelling, Hegel, Schopenhauer, Nietzsche, and Victor Cousin, just to name a few. Many of those thinkers were avidly read by the Dada artists and poets. ${ }^{18}$ In fact, Hugo Ball even wrote his dissertation on Nietzsche ${ }^{19}$ These individuals translated texts and/or made declarations about the nature of the texts from a western view point. According to Roger-Pol Droit, the West's conception of Buddhism went through different stages of definition based on the contributions of the individuals mentioned above. For instance, Buddhism is initially understood as mythology, but in 1817 Ozeray publishes a small book that declares that

\footnotetext{
${ }^{17}$ Ibid., 21.

${ }^{18}$ Won, $86 \& 90$.

${ }^{19}$ Dada: Themes and Movements, edited by Rudolf Kuenzli (London: Phaidon Press Limited, 2006), 16.
} 
the Buddha was a human being which "...marks a break; the move from myth to history. ${ }^{20}$ The western characterization of Buddhism changed as individuals, such as Ozeray, made additional contributions to the discussion. Nevertheless, it is Droit's assertion that "...it was not the state of available information that changed, but rather the way it was considered and the meaning it was given." ${ }^{21}$

Ozeray helped redirect the West's perspective and perhaps give more validity to a scholarly discussion of Buddhism by making it a historical fact rather than a mythological story. This perspective would again change as a particular theme became the focus of western investigations of Buddhism: “... a body of knowledge began to form...the scholarly study of the doctrines, and their interpretations, centered around the different registers of nihilism." 22 Buddhism was labeled nihilistic, a "religion of nothingness, ${ }^{23}$ and nirvana was equivalent to annihilation. These new characteristics assigned to Buddhism are considered negative and destructive by westerners and a threat to society. Droit believes that by the early 1890 s there was another shift in perspective and the label of a religion of nothingness was no longer applied to Buddhism: "There was undoubtedly no more nothingness, but neither was there much doctrine..." ${ }^{24}$ Buddhism was no longer an active threat, it had become benign. Still, the bulk of material available to artists and intellectuals by the 1900 s centered on the perceived nihilistic nature of Buddhism.

\footnotetext{
${ }^{20}$ Roger-Pol Droit, The Cult of Nothingness: The Philosophers and the Buddha, translated by David Streight and Pamela Vohnson (Chapel Hill: University of North Carolina Press, 2003), 37.

${ }^{21}$ Ibid., 38.

${ }^{22}$ Ibid., 47.

${ }^{23}$ Ibid., 4.

${ }^{24}$ Ibid., 157.
} 
The ways in which individual philosophers explored this feature vary. Their focus seems to be based, in part, on the best way the connection can be utilized in conjunction with their own philosophical theories already in existence. Westerner thinkers used their understanding of a feature of the East simply as a catalyst in their investigations of their own culture:

From Hegel to Nietzsche, passing through Schopenhauer, of course, it was always in reference to this imaginary Buddhism that the different strata of nihilism were approached: the identity of pure Being with nothingness, the negation of the will to live, the existence of a world of values. In this sense, the cult of nothingness served as sort of a hidden laboratory for the theoretical development of European nihilism. ${ }^{25}$

Take Nietzsche for instance, whose philosophy had a direct impact on Dada and was likely to be one of the means by which Dada was exposed to Buddhism. He was critical of Buddhism because he saw it as passively nihilistic. Nietzsche was not completely against nihilism, but saw it as a means to an end, a "transitional stage." $\mathrm{He}$ considered this to be "... active nihilism, i.e. nihilism that destroys the old 'lies' as a means to creating something new. Nihilism persists only as long as the 'error' persists. Once the error has been completely eradicated, nihilism ends. ${ }^{26} \mathrm{He}$ believed that Buddhism was only championing the destruction of life; it did not bring about a new and better world. This was considered dangerous because “...passive nihilism, which rather than seeing nihilism as a transitional stage, and surpassing it, sees it as the ultimate statement upon life: life actually is without any possible meaning or value. ${ }^{27}$ Nietzsche apparently misunderstood certain aspects of Buddhism. For Buddhism, the idea is to rid

\footnotetext{
${ }^{25}$ Ibid., 167.

${ }^{26}$ Robert G. Morrison, Nietzsche and Buddhism: A Study in Nihilism and Ironic Affinities (Oxford: Oxford University Press, 1997), 13.

${ }^{27}$ Ibid., 14.
} 
oneself of the constructions of society in order to have an unmediated experience of existence. It is definitely not a declaration that existence is valueless or pointless.

Life is only without the meanings that are conceived of in an artificial form and then imposed on the continuously altering mutability of reality. Meaning is simply “...the mind's attempt to grasp the fluid forms of nature in its mesh of fixed classes...The formal world becomes the real world in the moment when it is no longer clutched, in the moment when its changeful fluidity is no longer resisted. ${ }^{, 28}$ Buddhism focuses on living in this real, fluctuating world. Nietzsche's idea of creating new systems of perception would only continue to distance one from the natural world. The fact that Buddhism, and Dada, do not "clutch" at artificial forms does not equate to a belief that life is pointless. Only those conceptions of life in unalterable classifications are meaningless, just as rigid rules for art are meaningless and unnecessary in the world Dada artists found themselves. Alan Watts clarifies this issue perfectly by stating,

This is why the Hindu-Buddhist insistence on the impermanence of the world is not the pessimistic or nihilistic doctrine which Western critics normally suppose it to be. Transitoriness is depressing only to the mind which insists upon trying to grasp. But to the mind which lets go and moves with the flow of change, which becomes, in Zen Buddhist imagery, like a ball in a mountain stream, the sense of transience or emptiness becomes a kind of ecstasy. ${ }^{29}$

For Nietzsche, the idea of passive nihilism also indicated a lack of action. From his readings about Buddhism he understood nirvana as a state of non-action. Though this is an idea in Buddhism, as well as Taoism, what the term non-action denotes is not the release from every form of action. Thus, “...it would be a mistake to conclude that one who has realized nirvāna no longer acts. For example, after attaining nirvāna, the Buddha

\footnotetext{
${ }^{28}$ Alan Watts, The Way of Zen (New York: Vintage Books, 1957), 42.

${ }^{29}$ Ibid., 42.
} 
spent some forty-five or so years being very active..." ${ }^{\text {30 }}$ Obviously actions still occur, so the transfer of ideas through language, not to mention the translation from one language to another, has proven itself to be faulty. Robert Morrison offers a explanation of the notion of non-action, “...cessation of action (kamma nirodha) only implies the cessation of the kind of willing that creates the kind of 'consequences' (vipäkas) and 'fruits' (phalas) that keep one bound to unenlightened existence, the kind of willing that can only arise in the minds of unenlightened beings. ${ }^{31}$ The actions that cease are those that continue to invest one's being in the categorized world, actions that hinder one's ability to experience the world as it truly is.

After considering the ideas that Nietzsche had about Buddhism, and perhaps by extension Dada, it is interesting to note that some of his philosophical views actually resonate with concepts in Dada and Eastern thought. T.J. Berard sees Nietzsche's tragic culture as one of these views. He states that Nietzsche's vision of the tragic culture ...provides us with the idea that man can exist naturally, that is, without putting the lie to existence, by means of a culture which is rich in symbolic meaning, but without the symbols assuming foundationalistic or transcendental meaning, for example in dogma, moral codes or any other reification of human symbolic constructions. ${ }^{32}$

This natural existence without constructions of reality interfering is the central "principle" in Zen, Tao, and Zurich Dada. Symbols, words, and objects still exist but cannot be the basis through which one experiences life. One must be able to connect with

\footnotetext{
${ }^{30}$ Morrison, 43.

${ }^{31}$ Ibid., 44.

${ }^{32}$ T.J. Berard, "Dada between Nietzsche's Birth of Tragedy and Bourdieu's Distinction: Existenz and Conflict in Cultural Analysis," Theory, Culture \& Society 16, no. 1 (1999):

http://tcs.sagepub.com/cgi/content/abstract/16/1/141, 147.
} 
the spontaneous flow of existence and not be hindered by the "lie" society has formulated.

Considering the accounts above, westerners were clearly not even making an attempt understand or differentiate between the various sects or manifestations of Buddhism but were making generalizations and applying them to the East as a whole. It was not even until 1868 that the Tao Te Ching $^{33}$ was translated into English. Moreover, Droit's account emphasizes the fact the majority of the West's focus was on India and not the various countries and cultures Buddhism had spread to. Although India is the birthplace of Buddhism, when westerners were engaging in this subject of study during the eighteenth and nineteenth century Buddhism was basically nonexistent in the country, which predominately practiced Hinduism followed by Islam and Christianity.

The ways in which information about Buddhism was ascertained and circulated, not to mention the topic of nihilism in particular, exemplifies the fact that, "Under the cover of understanding a newly discovered and passably disconcerting Eastern religion, Europe composed an image of the Buddha made of what she feared in herself: collapse, the abyss, the void, annihilation." ${ }^{34}$ The East was used as a tool by the West to understand its own identity by measuring the similarities and the difference between cultures. Since the West is the one doing the observing and the one making declarations about the East based on a different cultural perspective, it is the West that has positioned itself as the authority. Thus, it is not necessarily problematic that the information being

\footnotetext{
${ }^{33}$ The Tao Te Ching is the principle Taoist text attributed to the founder of Taoism, Lao-tzu, who was a contemporary of Confucius. It consists of eighty-one brief chapters focused on the Tao (the way) and its $\mathrm{Te}$ (virtue or "thingness"). Though there is debate about the exact time Lao-tzu lived and when his writings were codified, the Toa Te Ching is usually dated from the late $4^{\text {th }}$ to early $3^{\text {rd }}$ century BC.

${ }^{34}$ Droit, $167-68$.
} 
"discovered" is warped or biased to a large extent, as long as that bias is in the West's favor.

The same unwillingness to move beyond the characterization of nihilistic, destructive, and negative applies to the art historic conception of Dada. In his 1971 book on Dada and Tristan Tzara, Elmer Peterson states:

With dadist vigor, Tzara says: “...il n’y a pas de commencement et nous ne tremblons pas, nous ne sommes pas sentimentaux. Nous déchirons, vent furieux, le linge des nuages et des priers, et préparons le grand spectacle du désastre, l'incendie, la decomposition." [There is no beginning and we do not tremble. We aren't sentimental. Like a furious wind we tear apart the linen of clouds and prayers, and we prepare the great spectacle of disaster, fire, and decomposition.] ... These proclamations make Tzara's intent clear...will to destruction... a nihilistic attitude... ${ }^{35}$

Roughly sixty years after Dada's beginning, scholars were still declaring the actions of Tzara and other artists to be destructive and nihilistic. However, Tzara's intent in this particular case can be interpreted in a different manner.

It seems the "great spectacle" being prepared for will occur regardless of these artists' actions or attitudes, and they are aware of this fact. Nonetheless, if one accepts the idea that decomposition leaves room for new growth, then one does not have to be "sentimental" and hold on to the past. Letting go of the past and experiencing or witnessing a moment of creation also means that one does not have to rely on the idea of one, single beginning. This idea is compatible with forms of eastern thought:

The universe is seen, both in Confucian and Daoist understandings as a natural process without a definite beginning in time and without a personal creator. ...Unlike Western thinkers, most Chinese philosophers do not hold to a definite or specific act of creation but rather view creation as an ongoing process of return to origins. ${ }^{36}$

\footnotetext{
${ }^{35}$ Elmer Peterson, Tristan Tzara: Dada and Surrational Theorist (New Brunswick, New Jersey: Rutgers University Press, 1971), 27-28.
} 
Reality is ever changing, but a fear of the unknown, the lack, the void is what hinders some individuals from letting go of a conception of existence that is no longer viable.

In rapidly modernizing Europe on the eve of the First World War, existence was clearly in a massive state of change. There is no debating the negative aspects that accompanied this altered existence. However, one can find "...reason and purpose in the destructiveness of the Dadaists. At the base of their actions was a very strong belief in human values and the means by which those values might be realized: in this sense they were neither anarchistic or nihilistic. ${ }^{37}$ Dada artists were not being indifferent to or taking pleasure in people's suffering. They were not turning their backs on life. Dada artists were trying to facilitate the removal of those aspects of existence that contributed to a state of global degeneration. For instance, the narrow focus on rational pursuits had created a mindset that there is a right and a wrong in every situation in life, a true and a false with no middle ground, and one must be on the right (true) side. Those on the side of the "truth" controlled the power, not only politically but economically, culturally, and morally as well. The struggle to maintain control of this power resulted in the widespread destruction of life. The old method of domination and subjugation by evoking the "truth" was threatening existence on a variety of levels, so a new understanding or perspective of reality was necessary for the cultivation of a new way of life.

The Dadaists were aware that the way in which reality was constructed was undergoing a transformation and this was a normal part of existence. The established truths had been proven to be faulty and humanity had to reassess its role and actions in

\footnotetext{
${ }^{36}$ Katrin Froes, Nietzsche, Heidegger, and Daoist Thought: Crossing Paths In-Between (Albany: State University of New York Press, 2006), 22.

${ }^{37}$ Allan C. Greenberg, Artists and Revolution: Dada and the Bauhaus, 1917-1925 (Ann Arbor, Michigan: UMI Research Press, 1979), 116.
} 
the world. Katrin Froes explains why such a reevaluation must occur: "All truths are eventually destroyed by the flux of nature. Truths can achieve stability only by leaving something out, but that which is left out eventually forces us to engage in a renewed process evaluation. ${ }^{38}$ The western world had been so focused on rational pursuits and suppressing those features deemed irrational, when chaos began approaching there was fear of complete destruction. Dadaist's encouraged a new manifestation of life, so there was an understanding on their part that some amount of deconstruction was necessary.

Appreciation of the "flux of nature" is not confined to Dada. During this period of modernity, it has become clear to many individuals that the tenets of the past cannot provide a foundation for this new world. This would only hold people back, tie them down to the past, and force them to live a life based on previous conceptions that may no longer be relevant. Richard Sheppard highlights the link between this new atmosphere of modernization and Eastern thought stating,

...a host of writers and artists during the modernist period were attracted to, afflicted by, or became active proponents of the idea that reality is energetic and fluctuating. ... It was almost certainly for the same reason that so many writers and intellectuals...were drawn to Eastern philosophy, especially Taoism, with its central doctrine of reality as a flux of opposing forces that the individual must somehow hold in dynamic balance. ${ }^{39}$

One must be able to recognize that good and bad, right and wrong, up and down, left and right are simply two aspects of the same thing and that one would not exist with out the other. When this is taken into perspective and one focuses on the connectedness of the world, the fear of the unknown begins to subside. One knows that where "destructive" forces have caused a void, there is room for creation. For Taoism,

\footnotetext{
${ }^{38}$ Froes, 31 .

${ }^{39}$ Sheppard, 39-40.
} 
...opposition to moral dogmatism is not intended to foster reckless moral abandon, but rather allows the sage to resolve conflict in a more contextualized manner. An attunement to nothingness can help foster a kind of moral pragmatism which neither relies solely on the applications of abstract rules, nor depends on an unthinking compliance with rigid moral rituals. 40

One is not forced to make decisions about life based on previously established standards, but instead come to a view of the world based on the present reality one is faced with. As modernization was changing the terrain of existence, people could no longer subscribe to the rigid categories of the past.

Sheppard calls attention to Dada's interest in understanding and achieving balance a number of times. Stating, in fact, that there is an "...'Empedoclean problem' that is so central to Dada: is reality chaotic, patterned, or a perspectival mixture of chaos and pattern that must be held in balance?" ${ }^{41} \mathrm{He}$ also connects this central issue of searching for balance to the Bhagavad Gita ${ }^{42}$, which Hans Arp created illustrations for in $1914 .{ }^{43}$ Dada and eastern thought obviously have various similarities in their perspective of reality. However, one cannot forget the fact that, as westerners, Dada artists had a conception of the East that was constructed by the West. Their perspectives may be similar, but they are not completely equivalent. Nevertheless, highlighting the parallels between the two does provide a different conception of Dada and helps encourage a reconsideration of the label of nihilism both in Dada and eastern thought, as applied by Western thinkers.

\footnotetext{
${ }^{40}$ Froese, 147.

${ }^{41}$ Sheppard, 269.

${ }^{42}$ The Bhagavad Gita is a 700-verse Hindu scripture from the Vedic tradition that is comprised of a conversation between Krishna and prince Arjuna, which summarizes Hindu theology.

${ }^{43}$ Sheppard, 282.
} 
Section Three: A Comparison of Zurich Dada and Eastern Philosophies

A variety of Dada artists made declarations about Dada and/or created art that can be related to Eastern philosophy, in particular to Zen and Taoism. Richard Sheppard has documented the direct contact that some Dada artists had to various texts on Eastern though. He writes:

...Hausmann claimed that from about the age of sixteen he had read the pre-Socratics, Lao-Tzu, Buddhist texts,...Hannah Höch's library included Martin Buber's edition of Reden und Gleichnisse des Tschuang-Tse (Sayings and Parables of Chuang Tzu) and Die Bahn und der rechte Weg des Lao-Tse, a German translation of the Tao Te Ching that had been given to her by Hausmann on 11 February $1916{ }^{44}$

Sheppard also notes that Julius Evola, a principal Italian Dada artist, translated and published the Tao Te Ching into Italian in the early $1920 \mathrm{~s} .{ }^{45}$ Although the Dadaists mentioned by Sheppard were active mainly in Berlin and Italy, they were not alone in their interests. Their counterparts in Zurich also found something valuable in the writings of Taoism and Buddhism.

Richard Hülsenbeck made specific references to a connection between Dada, Buddhism, and Taoism. It seems apparent from his statements that he was quite familiar with writings on Eastern thought, and felt comfortable in his understanding of the texts to recognized comparisons to ideas in Dada. In fact, one of the prefaces in his 1920 Dada Almanach is section twenty-eight from the Tao Te Ching. Sheppard observed that in the introduction "...Huelsenbeck wrote... 'Dada is the American aspect of Buddhism; it blusters because it knows how to be quiet; it agitates because it is at peace.",46 Proclamations such as this serve as a reminder that Dadaists are not actually practicing

${ }^{44}$ Ibid., 276.

${ }^{45}$ Ibid., 277.

${ }^{46}$ Ibid., 279. 
Buddhism or Taoism, however, their attitude toward life and consciousness of being have some sort of relationship to practices and ideas in these two forms of Eastern thought.

In another work Hülsenbeck linked Nirvana and Dada together, stating, "Gautama thought he was going to Nirvana, and when he died, he stood not in Nirvana but in dada. ${ }^{, 47}$ In this instance he did not simply compare concepts associated with Dada to those of Buddhism, but made them interchangeable. Hülsenbeck did this again when he remarked, "Yes, yes, dada cannot be unveiled. Dada multiplies everything to the hundredth and thousandth degree. Tao and brama are dada." ${ }^{, 48}$ Here he equated the concepts and built the link further by calling attention to their mysterious natures. The idea of multiplying things could be a comment on the notion that all pieces of reality are one whole, thus the one thing indicates all things. Hülsenbeck may have developed this notion from reading Lao Tzu's discussion of the ten thousand things in the Tao Te Ching.

Other direct references to the East surface in descriptions Dada artists made about one another. For instance, it is clearly evident that Hugo Ball had some familiarity with eastern culture. An account by Hans Richter states,

Everything Janco touched had a certain elegance, even his horrific abstract masks. Ball says of them: "Janco has made a number of masks for the new show, which bear the marks of something more than talent. They recall the Japanese or Ancient Greek theater, and yet they are wholly modern..."49 (Figure 3.1)

Ball instantly connected these "modern" artworks to forms of art that were at a distance from Dada activities; culturally and geographically in the case of Japan, and distanced by the passage of time in relation to Ancient Greece. Ball was implying that certain features

\footnotetext{
${ }^{47}$ Richard Hülsenbeck, "Invest in Dada!," in Dadas on Art, ed. Lucy R. Lippard (Englewood Cliffs, NJ: Prentice-Hall, 1971), 56.

${ }^{48}$ Ibid., 56.

${ }^{49}$ Hans Richter, Dada: Art and Anti-art (New York: Harry N. Abrams, Inc., 1964), 23.
} 
of artistic creation were universal in some sense. What may appear to be quite divergent on the surface can actually be linked by philosophy or imagery, and Ball has verbally united Dada with Japan. (Figure 3.2) Nevertheless, the visual connection that Ball made combined with the awareness that the objects in question were not derivative emphasizes the fact that Dads was not making Zen or Taoist art as such, but establishing a relationship between Dada and the East.

The writings of artists associated with Zurich Dada abound in less explicit links to Eastern philosophy. The case in point is Tristan Tzara's Manifeste Dada 1918. It was included in the Dada periodical, Dada No.3. Tzara read the manifesto aloud at one of the Dada gatherings. Rudolf Kuenzli describes the impact of this piece of writing: "André Breton read the manifesto in Paris. 'But it is only with Dada No.3, which arrived in Paris at the beginning of 1919 ', Breton wrote, 'that things ignited..." ${ }^{50}$ Tzara's manifesto exemplifies the desire to abolish any imposed rules for creating art. ${ }^{51}$ It is also interesting to note that diagonally across the cover of this particular Dada publication is a quote from Descartes that states, "I do not even wish to know if there were men before me." (Figure 3.3) In his book, Dada: Art and Anti-art, Hans Richter explains that,

The myth that everything in the world can be rationally explained had been gaining ground since the time of Descartes. An inversion was necessary to restore balance. The realization that reason and anti-reason, sense and nonsense, design and chance, consciousness and unconsciousness, belong together as necessary parts of a whole - this was a central message of Dada. ${ }^{52}$

In the manifesto, Tzara emphasizes contradictions by stating, “....in principle I am against manifestos, as I am also against principles...I write this manifesto to show that

\footnotetext{
${ }^{50}$ Dada, 20.

${ }^{51}$ Ibid., 20.

52 Richter, 64.
} 
people can perform contrary actions while taking one fresh gulp of air..."53 The dualistic structure of conception implies and gives meaning to things by way of a relation to their opposites. Dada is attempting to move beyond this frame of thought since, in reality, opposites are actual just the two sides of one thing. This notion exists in Zen as well, which believes that "Choosing is absurd because there is no choice." ${ }^{, 54}$ Taoism, as well, clearly recognizes this interdependence of opposites:

It was a first principle of Taoism that 'When everyone recognizes beauty as beautiful, there is already ugliness; When everyone recognizes goodness as good, there is already evil...' To see this is to see that good without evil is like up without down, and that to make an ideal of pursuing the good is like trying to get rid of the left by turning constantly to the right. One is therefore compelled to go round in circles. ${ }^{55}$

Thus, if one consistently tries to follow one specific side of an idea then half of reality is being ignored. To understand life one must recognize and come to terms with all of its features.

Tzara's Manifesto goes on to question the validity of classifications since these are the arbitrary results of the use of language. He believes that some people have "....an absurd view of life, which they have classified, cut into sections, channelized: they insist on waving the baton as categories dance. ${ }^{, 56}$ The world is constructed and made intelligible through descriptions that generalize objects and events allowing broad labels to be imposed on anything that is even remotely similar. Thus, society makes or builds its own knowledge of reality. However, for a Taoist the universe grows; it is not constructed,

\footnotetext{
${ }^{53}$ Tristan Tzara, "Dada Manifesto," in Between Worlds: A Sourcebook of Central European Avant-gardes, 1910-1930, ed. Timothy O. Benson and Éva Forgács (Los Angeles: Los Angeles County Museum of Art, 2002), 313-317.

${ }_{55}^{54}$ Alan Watts, 117.

${ }^{55}$ Ibid., 115-16.

${ }^{56}$ Tristan Tzara, 314.
} 
and "...a universe which grows utterly excludes the possibility of knowing how it grows in the clumsy terms of thought and language, so that no Taoist would dream of asking the Tao how it produces the universe. For it operates according to spontaneity, not according to plan. ${ }^{, 57}$ This spontaneous process is beyond description and the descriptions people have attempted to use are considered to be inferior. The categories of language separate one from the direct experience of existence by mediating it through fabricated conceptions. Thus, to explain or speak of this direct experience accurately through words is impossible, hence the Zen idea of "direct-pointing."

Finally, Tzara sees the rational world as fake and disingenuous as compared to actual reality. The "rational" world is created by individuals in society dictating the knowledge that is available and how it is presented to and understood by the world. Real existence, life that has not been mediated by classifications, consists of the blending together of all the opposites that have been separated. Encouraging or bringing about an awareness of the connectedness of reality is a focus for Dada, Taoism, and Zen. Tzara states, "Freedom: Dada, Dada, Dada, a roaring of tense colors, and interlacing of opposites and of all contradictions, grotesques, inconsistencies: LIFE. ${ }^{58}$ Dada, like Zen and Taoism, views existence as a unitary process.

This unitary process is ignored and denigrated when one's thoughts are regulated to narrow conceptions that only represent a piece of that existence. Robert Morrison points out:

Existence...from the Buddhist point of view, is a fluctuating continuum with no gaps between the bits we categorize as 'self $A$ ' and 'self B,' or 'cause' and 'effect.' Interestingly enough, this is how Nietzsche sees it: 'cause and effect: such a duality probably

\footnotetext{
${ }^{57}$ Alan Watts, 17.

${ }^{58}$ Tristan Tzara, 317.
} 
never exists; in truth we are confronted by a continuum out of which we isolate a couple of pieces,..., 59

Artists, philosophers, Taoist sages, and Zen masters are all thinking about existence in similar ways, although the extent to which each is able to truly participate in a connected and flowing reality may vary greatly. Richard Sheppard believes, "There is...a clear analogy between Dada's vision of reality as unending process and the Taoist concept of the Tao (Way) that flows freely, mysteriously, and indifferently as the creative ground of all things. ${ }^{\prime 60}$ To be one with the Tao is to experience reality without conceptual barriers that restrict one's thoughts and the way in which life is experienced.

In Zurich, Hans Richter comments that Dada artists felt as though they were not constrained by societal conventions. This release from the established order gave Dadaists the opportunity to connect with the aspects of existence that have been ignored because they could not be given a precise label. Richter explains, "Our feeling of freedom from rules, precepts, money, and critical praise...was a major stimulus...The absence of any ulterior motive enabled us to listen to the voice of the 'Unknown'—and to draw knowledge from the realm of the unknown. Thus we arrived at the central experience of Dada." ${ }^{61}$ Without having to think, work, and live within the confinement of established conventions, Dada artists saw an opportunity to experience existence as it is, in that unknown form that could not be named.

The notion of exploring the unknown and attempting to connect with it is the main concept of Taoism. The Tao is the unknown force that the Taoist sage comes into harmony with, the flow of existence. When speaking of the Tao,

\footnotetext{
${ }^{59}$ Morrison, 183.

${ }^{60}$ Sheppard, 283.

${ }^{61}$ Richter, 50.
} 
In the words of Lao-tzu's great successor, Chuang-tzu: 'Things are produced around us, but no one knows the whence. They issue forth, but no one sees the portal. Men one and all value that part of knowledge which is known. They do not know how to avail themselves of the Unknown in order to reach knowledge. Is not this misguided?' 62

For Taoism everything that humanity "knows" has been constructed by humanity itself, but this is only one part of existence. In order to be aware of the whole of existence, one has to be willing to consider life in relation to the unknown, the lack, the void. Although Richter does not directly reference Buddhism or Taoism, it is clear that his consideration of the unknown as being a source of knowledge that is not connected to the constructions of reality has an affinity with the idea of the Tao. Additionally, it is evident by some of his artworks that Richter had an awareness of Eastern culture.

Recognition of the unknown extends to Richter's production of art in an interesting way. In 1918 he started creating scroll paintings as a “...rejection of

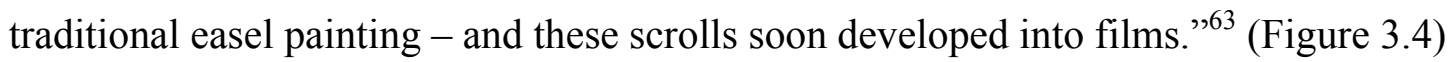
The technique of scroll painting is "unknown" in the traditional European cannon of art. Richter's freedom to explore the unknown translated into a freedom from tradition, but this was executed by appropriating a technique from a different, and more specifically Eastern, tradition.

Marcel Janco speaks of the association of Dada with the nature of a child. Janco states, "The word Dada itself already has a new meaning for us; a synonym for pure, childlike, direct, primal." 64 The idea of encouraging a childlike way of thinking is brought up in Zen and Taoism. To think like a child is to have a mind that is open and

\footnotetext{
${ }^{62}$ Alan Watts, 17.

${ }^{63}$ Dada, 67.

${ }^{64}$ Marcel Janco, "Dada at Two Speeds," in Dadas on Art, ed. Lucy R. Lippard (Englewood Cliffs, NJ: Prentice-Hall, 1971), 36.
} 
untainted. This mode of thought is one that is not complicated and distanced from existence by a systematic view of life. It should be made clear that "The idea is not to reduce the human mind to a moronic vacuity, but to bring into play its innate and spontaneous intelligence by using it without forcing it." ${ }^{, 65}$ Children have to be taught the rules, categories, and basic way of thinking and communicating that a society creates. Thus, if one can see reality as a child does before he or she has been educated in this way, then one's mind will be freer and naturally connected to the world around, the fluctuating existence that is the Tao.

Taoists view reality as a stream of existence where all possible manifestations of life flow together. The need to mentally separate and classify aspects of reality puts one at a distance from the actual world one is experiencing. The result is that one experiences his or her mental conception of the world and not actual reality. Since these mental abstractions differ from person to person misconceptions or misunderstandings occur easily. One must aspire to a perception that is not entangled in this constructed, arbitrary world. Nonetheless, the ability to see through the false boundaries of society is an extremely difficult task and is not something that can be taught or explained.

When one is able to experience life without the mediation of such boundaries, one is described as having reached enlightenment, Nirvana, Satori, or awakening. Although this realization about existence is difficult to put into words,

...awakening is something quite natural, something startling obvious, which may occur at any moment. If it involves difficulty, it is just that it is much too simple. Zen is also direct in its way of teaching, for it points directly and openly to the truth, and does not trifle with symbolism. ${ }^{66}$

\footnotetext{
${ }^{65}$ Alan Watts, 21.

${ }^{66}$ Ibid., 77.
} 
Since words and language are symbols of this constructed world, it is understandable that one cannot employ these tools directly to alter one's understanding of existence. This is why "If you asked a Zen-Master just what is Satori, he might smile or scowl at you, or give an answer like 'the stream flows on.' Or he might simply give you a couple of good blows with his stick." ${ }^{67}$ This is supposed to snap one out of the normal frame of mind to reach a view of life that is beyond labels, categories, and conventions. Performances at the Cabaret Voltaire in Zurich used this same type of technique.

The Cabaret Voltaire, named “....in honour of the eighteenth-century French writer, philosopher and radical critic, ${ }^{, 68}$ was short lived but set the tone for future Dada activities. The cabaret lasted only five months, opening in early February 1916 and closing in early July of that same year. Hugo Ball and his girlfriend Emmy Hennings started the cabaret and were quickly joined by Tristan Tzara, Marcel Janco, Hans Arp, Richard Hulsenbeck, and Hans Richter. The artists read poems, performed plays, danced, executed musical performances, and engaged in various manners of artistic activity, but these did not adhere to the traditional artistic format. (Figure 3.5) Arp attempts to convey the atmosphere of the cabaret:

Total Pandemonium. The people around us are shouting, laughing and gesticulating. Our replies are sighs of love, volleys of hiccups, poems, moos, and meowing of medieval Bruitists. Tzara is wiggling his behind like the belly of an Oriental dancer. Janco is playing an invisible violin and bowing and scraping. Madame Hennings, with a Madonna face, is doing the splits. Huelsenbeck is banging away nonstop on the great drum, with Ball accompanying him on the piano, pale as a chalky ghost. ${ }^{69}$

\footnotetext{
${ }^{67}$ Ibid., 199.

${ }^{68}$ Dada, 18.

${ }^{69}$ Ibid., 18.
} 
Comments by Hans Richter corroborate the chaotic activity that occurred in that small café in Zurich:

Bells, drums, cow-bells, blows on the table or on empty boxes, all enlivened the already wild accents of the new poetic language, and excited, by purely physical means, an audience which had begun by sitting impassively behind its beer-mugs. From this state of immobility it was roused into frenzied involvement with what was going on. This was Art, this was Life, and this was what they wanted $!^{70}$

The Dada artists attempted to shock and confuse the audience as a way of interrupting their habitual perspective of reality, similar to the Zen master. Ioana Vlasiu explains “...purpose was to... jolt spectators from inertia and unleash a new sensibility in them. The protagonists of these spectacles looked for 'liberated words' that would negate grammatical rules, and cultivated the absurd and nonsensical." ${ }^{, 71}$ The Zen master and the Dada performances exhibit an effort not to rely on conventional forms of communication because they are inadequate and defective.

For the Dada artists, this extends to conventional art forms as well. For instance, the resistance to the standard format of language is shown by Hugo Ball's creation of sound poetry. (Figure 3.6) Not to mention that his cubist-style costume worn while performing the sound poem, Karawane, is a clear dismissal of the traditional form and presentation of poetry. (Figure 3.7) Although the art created by the Dadaists in Zurich manifested itself in various and divergent forms,

...members of the group seemed agreed that their activities were aimed in part at producing a new type of consciousness, which sat outside of conventional morality and institutional frame worksand which...might best be described as a kind of assertive and self-conscious amorality, or individual revolt against systemic

\footnotetext{
${ }^{70}$ Richter, 19.

${ }^{71}$ Ioana Vlasiu, "Bucharest," in Central European Avant-gardes: Exchange and Transformation, 19201930, ed. Timothy O. Benson (Los Angeles: Los Angeles County Museum of Art, 2002), 247-254.
} 
orders. $^{72}$

In this "revolt against systemic orders," the problems that language produces are an important concern for Dada, Zen, and Taoism. In fact, “... Dada sought to formulate its ideas obliquely, ironically, and in unfamiliar idioms to make it harder for them to be assimilated and deprived of their subversive force. ${ }^{, 73}$ Expressing ideas in this fashion is akin to a Zen master's koan. Two well known examples are: Tung-shan's reply when a monk asked him "Who is the Buddha?" and he simply states, "Three chin of flax,"74 and a Zen master asking a pupil what is the sound of one hand clapping. Clearly these two instances are not predictable forms of communication between individuals, and they are not supposed to be. The point is not to gain knowledge through a question and answer session that has a correct or factual response. D.T. Suzuki explains,

Technically speaking, the koan given to the uninitiated is intended 'to destroy the root of life,'... This may sound murderous, but the ultimate intent is to go beyond the limits of intellection, and these limits can be crossed over only by exhausting oneself once for all... Logic then turns into psychology, intellection into conation and intuition. What could not be solved on the plane of empirical consciousness is now transferred to the deeper recesses of the mind. $^{75}$

The traditional mode of thinking must be broken, or perhaps a better description would be that one must break through it. In order to create something new, one needs to let go of the old and shift gears. When one is fully experiencing reality it is unnecessary to engage one's mind into rational turmoil and force various ideas into arbitrary categories to be judged morally or socially depending on the time and place.

\footnotetext{
72 Dickerman, 25.

${ }^{73}$ Sheppard, 267.

${ }^{74}$ Zen Buddhism: Selected Writings of D.T. Suzuki, edited by William Barrett (New York: Three Leaves Press, 2006), 159.

75 Ibid., 164-65.
} 
Another instance of Dadaists rejecting the normal approach to language is Tzara's 1916 Zurich play, Première Aventure céleste de M. Antipyrine, in which he “...playfully repeats last syllables or groups of syllables...the purpose being to point up the hollowness of words and to confirm the belief that rational communication is often absolutely impossible." ${ }^{, 76}$ Another early example of Dada artists challenging the structure of verbal communication was the recital of the simultaneous poem, The Admiral is Looking for a House to Rent. (Figure 3.8) It was performed by Richard Hüelsenbeck, Tristan Tzara, and Marcel Janco at the Cabaret Voltaire in 1916 in three different languages. Although the work is "Legible as a typeset script, when recited, the work provided a form of semantic overload, with words colliding cacophonously in a field of sound so that meaning was rendered only partially intelligible.,"77 The layering of words or their replacement by sound is not the only way in which the established form of communication can be challenged and shown to be haphazard. Ko Won calls attention to the fact that the words used to describe Buddhism and Taoism are complex and indicate multiple, often opposed, meanings, so the words become inclusive of all the aspects of reality they are expressing. He states,

In short, 'nothing' in Buddhism is theoretically and practically denotative of 'everything.' This seemingly paradoxical equation is very often similar to Taoism, in which,...the Chinese word ch'ung, used in Tao-te-ching, verse IV, to define the character of the Tao, means both 'full' and 'empty' ('formless'); hence it is possible to render the opening line in two ways: 'Tao is all-pervading'; and 'The Way is empty. ${ }^{, 78}$

Obviously the use of language can cause the concept one is discussing or trying to convey to be very confusing, and often the point may be lost in the transfer of ideas.

\footnotetext{
${ }^{76}$ Peterson, 11-12.

${ }^{77}$ Dickerman, 26.

${ }^{78}$ Won, 93.
} 
Additionally, Alan Watts believes that the Chinese language has somewhat of an edge on conceiving of a more connected world. He asserts that ".... a great number of Chinese words do duty for both nouns and verbs - so that one who thinks in Chinese has little difficulty in seeing that objects are also events, that our world is a collection of processes rather than entities. ${ }^{, 79}$ Fundamental to Taoism and Zen is the idea that reality is a process as opposed to an assortment of things that must be named and approached individually or in designated groups. Existence flows, it is not built.

Dada, Zen, and Taoism also share an interest in spontaneity and chance. The notion of chance plays an important role in Dada because it rejects an imposed rational order that requires the creation of art along established guidelines and boundaries. The removal of such constrictions allows for the freedom and flexibility of ideas that can be expressed in a way that encourages a more expansive and open-minded reception of art. Sheppard cautions, however, “...retrospective claims, like those concerning the role and status of chance, are easily made but somewhat exaggerated. To begin with, the Dadaists, especially those in Zurich, were experimenters." ${ }^{, 80}$ Obviously, those who are inclined to make experimentation a major feature in their art are aware and willing to allow elements of chance to contribute. Nevertheless, this fact does not negate the possibility that some Dada artists embraced chance and spontaneity in a way that resembles aspects of Zen and Taoism.

The most noticeable use of chance in Dada is by Hans Arp, and Harriett Ann Watts links Zen and the I Ching (or Book of Changes) to Arp's discussion of his artwork. She reports that "He refers to Zen in his description of the papier dechires, and he admits

\footnotetext{
${ }^{79}$ Alan Watts, 5.

${ }^{80}$ Sheppard, 267.
} 
in an interview that his first papier colles - i.e., Zurich 1915-16-were made under the influence of an 'ami occultiste,' whom [Herbert] Read believes must have introduced Arp to the I Ching at that time." ${ }^{, 11}$ It is evident that the artist has some association and understanding of Zen and Taoism. Watts illustrates this link through Arp's possible familiarization to the I Ching, however, a more direct association is in fact mentioned by Sheppard:

In 1914 [Arp] did a series of illustrations for the Bhagavad Gita (c. 800 B.C.).... He claimed in retrospect that the Zurich Dadaists used mandalas as models, and he appeared in Otto Flake's roman à clef about Zurich Dada as a devotee of Jakob Boehme and Lao-Tzu... ${ }^{82}$

The author provides clear documentation that Zurich Dadaists were aware of writings about features of Buddhism and Taoism. Not to mention, in Arp's case, the production of art for the Hindu text Bhagavad Gita.

The chance operations used by Arp to create his collages can be related to the Eastern idea of te, often described as the thingness of a thing or its potential. Alan Watts explains that te lies at the foundation of aesthetic production in Eastern cultures:

...these arts employ what are, to us, highly difficult technical disciplines, it is always recognized that they are instrumental and secondary, and that superior work has the quality of an accident.... for what the culture of Taoism and Zen proposes it that one might become the kind of person who, without intending it, is a source of marvelous accidents. ${ }^{83}$

Arp's process of tearing paper and letting the pieces fall randomly can be equated with such a marvelous accident. (Figure 3.9) However, like the technical discipline that aids in the creation of Eastern art, Arp did not confine himself to chance procedures alone.

\footnotetext{
81 Harriett Ann Watts, 90.

${ }^{82}$ Sheppard, 268.

${ }^{83}$ Alan Watts, 28-29.
} 
The artist employed methods of chance in the same way one is to approach the $I$ Ching. It is not a strict dictation of action that must be followed precisely, but is an action of chance as a means of pointing in a general direction. For Arp, his "most fruitful experimentation with chance consists in his allowing random intrusions to offer him new points of departure... a stimulus to further variations, not to a 'canned,' inalterable result. ${ }^{84}$ (Figure 3.10) The I Ching is often narrowly defined as a divination book. However, the point is not to provide the practitioner with knowledge of his or her future. The I Ching can only aid one in coming to a decision that the mind had actually already made. Alan Watts expounds on this concept by stating,

...decisions depend upon "hunch"-in other words "peripheral Vision' of the mind. Thus the reliability of our decisions rests ultimately upon our ability to 'feel' the situation, upon the degree to which this 'peripheral vision' has been developed. Every exponent of the I Ching knows this. He knows that the book itself does not contain exact science, but rather a useful tool which will work for him if he has a good 'intuition,' or if, as he would say, he is 'in the Tao. ${ }^{85}$

Thus, the I Ching is not a prophecy on what is to come or how one should act, but is instead similar Arp's method for using chance as a point of departure that encourages one to follow his or her natural instinct.

This sense of chance and spontaneity is also prevalent in poetry performed by Arp with his Dada counterparts. Richter even provides documentation that Arp had some awareness of Buddhism via his discussion of "automatic poetry."

And Arp tells us: "In the Café de la Terrasse, Tzara, Serner and I wrote a cycle of poems entitled Die Hyperbel vom Krokodilcoiffeur und dem Spazier-stock ("The Hyperbel of the Crocodile's Hairdresser and the Walking-Stick"). The Surrealists later christened this kind of poetry 'Automatic Poetry.' Automatic

\footnotetext{
${ }^{84}$ Harriett Ann Watts, 52.

${ }^{85}$ Alan Watts, 15.
} 
poetry springs directly from the poet's bowels or other organs, which have stored up reserves of usable material. Neither Postillion of Longjumeau nor the hexameter, neither grammar nor aesthetics, neither Buddha nor the Six Commandment should hold him back...",86

The fact that Arp list various ideas, interests, and historical figures as being unable to stop poetry from flowing freely out of the artist indicates his understanding of a more Taoist or Zen notion of reality in which the flux of existence does not allow for conformity to established ideas or institutions. Conventions and imposed moral standards do not hold up against the ever changing reality of time. For the Dadaists, the current apex of time, culture, and history resulted in logic becoming illogical and counter to human existence. Thus, those features of reality that were once deemed illogical have become a more authentic experience of life; one that was not confined by arbitrary standards but allowed to grow and reinvent the conception of life.

Arp's spontaneous perception eventually led him to create his automatic paintings. (Figure 3.11) New experimentation "...developed into a self-generative or 'automatic' process, in which Arp moved his brush over the surface of the paper quickly, attempting to avoid conscious inhibition or control in the creation of form." ${ }^{, 87}$ He relied on spontaneous action that was not blocked by the restrictive principles that institutions and conventional thinking often inflicted on aesthetic production. These automatic paintings are remarkably similar to Zen calligraphic paintings. A description of this type of painting, Sumi-e in Japanese, highlights its affinity to Arp's work:

...the touch of the brush is so light and fluid, and since it must move continuously over the absorbent paper if the ink is to flow out regularly, its control requires a free movement of the hand and arm as if one were dancing rather than writing on paper. In short, it

\footnotetext{
${ }^{86}$ Richter, 30.

${ }^{87}$ Harriett Ann Watts, 38.
} 
is a perfect instrument for the expression of unhesitating spontaneity, and a single stroke is enough to "give away" one's character to an experienced observer. ${ }^{88}$

Though there is mention of control in the production of the calligraphic painting it is a kind of effortless control that happens impulsively because one is attuned to the natural state of the mind that allows for instinctual action.

The Dada artists parallel Buddhism and Taoism in their consideration of the idea of non-action as well. From the Taoist point of view, the principle of non-action is similar to wu-wei which is understood as "action through inaction" or "effortless action." Take for consideration, "One Taoist saying is 'The Tao does not do anything. Yet through it, all things get done." ${ }^{, 89}$ Non-action and wu-wei refer to the idea of relying on natural instinct, as is associated with the I Ching. One is encouraged to come to "...decisions spontaneously, decisions which are effective to the degree that one knows how to let one's mind alone, trusting it to work by itself." 90 The point is that one's actions are not forced or controlled by social requirements or restrictions, they simply occur and one does not desire or will for inconsequential aspects of life that others place a great deal of significance on.

In Tristan Tzara's Manifeste Dada 1918 he alludes to the idea of non-action. He states "Measured by the scale of eternity, all activity is vain..." Tzara does not mean that all action and activity on earth should stop. He simply sees the activities that individuals have engaged in while striving to reach a certain goal or end that mankind has constructed for itself as unnecessary. This is evident in Zen art as well. For instance, “...the words of a Zenrin poem: 'The wild geese do not intend to cast their reflection;

\footnotetext{
${ }^{88}$ Alan Watts, 178.

${ }^{89}$ Raymond M. Smullyan, The Tao is Silent (San Francisco: Harper Collins, 1977), 158.

${ }^{90}$ Alan Watts, 19.
} 
The water has no mind to receive their image.' Thus the aimless life is the constant theme of Zen art of every kind, expressing the artist's own inner state of going nowhere in a timeless moment." ${ }^{91}$ Actions and events transpire naturally and have been doing so since before society came up with labels and prescriptions for these acts. Nevertheless, some thinkers still regard this association with non-action as a nihilistic tendency for Dada. Elmer Peterson mentions this same quote by Tzara and believes that from it “...one can discern a paralyzing nihilism..." , also referring to this as "extreme dadaist nihilism."

Hüelsenbeck made certain statements that could be considered an attempt to counter the negative stigma attached to Dada due to the trait of nihilism. He mentions the fact that the term nihilism constitutes a theory created by humans. It is the product of the process of segmenting and defining an element of reality and then a negative value is assigned to the notion. Hüelsenbeck explains,

It has become sufficiently apparent in our time that law, order, and the constructive, the 'understanding for an organic development' are only symbols, curtains, and pretexts for fat behinds and treachery. If the Dadaists movement is nihilism, then nihilism is a part of life, a truth which would be confirmed by any professor of zoology. ...Dada does not take a dogmatic attitude. ${ }^{93}$

People perceive elements in Dada that they can only understand by referencing one of the categories of life that has been set up. When one encounters something unfamiliar the first instinct is not to simply experience the concrete reality being presented, but to analyze, define, and group the new object or event into a previously established conception. This allows one the (false) comfort of believing that he or she knows this new feature of existence. Dada is trying to see existence beyond the veil that blankets it. Dada

\footnotetext{
${ }^{91}$ Ibid., 181.

${ }^{92}$ Peterson, 28.

${ }^{93}$ Richard Hülsenbeck, "Dada Forward," in Dadas on Art, ed. Lucy R. Lippard (Englewood Cliffs, NJ: Prentice-Hall, 1971), 52.
} 
has not upon held any ideology or doctrine because such conceptions are part of the veil, so the label of nihilism is incorrect.

Still, like the Tao that is both full and empty, if features of what has been termed nihilism are in Dada it is only because they are a part of the whole existence and cannot be removed from the natural world. In order to have an awareness of the entirety of the world (to be one with the Tao), one must embrace all aspects of life. Destruction and creation rely on one another. For the flux of life to continue and perpetual creation to come about, certain facets must fall into the void, where lack encourages growth. Sheppard explains how many Dada artists are attempting to come to terms with an existence that is experiencing the extreme opposites life has to offer. For instance, he mentions Hausmann and Hüelsenbeck and believes that for them "....it was a question not of withdrawing from the harsh realities of modernity, but of confronting them and finding a way of keeping one's balance amid their threats, fluctuations, and contradictions." 94 One cannot ignore the harsh features of reality that are a constant presence in one's life, but if one is fully aware and understands that all aspects of life are connected it may be easier to keep one's balance.

This notion of balance is also mentioned by Hans Richter and is used to rebuff the anarchistic label assigned to Dada. He states,

Compared with all previous 'isms,' Dada must have seemed hopelessly anarchic. But for us, who lived through it, this was not so. On the contrary, it was something meaningful, necessary and life-giving. The official belief in the infallibility of reason, logic and causality seemed to us senseless - as senseless as the destruction of the world and the systematic elimination of every particle of human feeling. This was why we were forced to look for something which would re-establish our humanity. What we needed to find was a 'balance between heaven and hell,' a new unity

\footnotetext{
${ }^{94}$ Sheppard, 280.
} 
combining chance and design. ${ }^{95}$

The reason and logic that had been advocated throughout history and used to give meaning to life lead to war on a global scale. Clearly there was something faulty in that logic and reason, so Dada artists searched another source to provide meaning. It seems that Eastern thought facilitated in this exploration. Taoism and Zen Buddhism both recognize that all aspects of reality are intertwined. When one feature, such as reason, is emphasized more than another, the focus can become so narrow that this feature is disconnected from the whole of reality and becomes somewhat meaningless. For the Dada artists, reason and logic turned out to be irrational and illogical, thus a new perception of reality was needed that did not have such a detrimentally narrow focus.

\footnotetext{
${ }^{95}$ Richter, 58.
} 


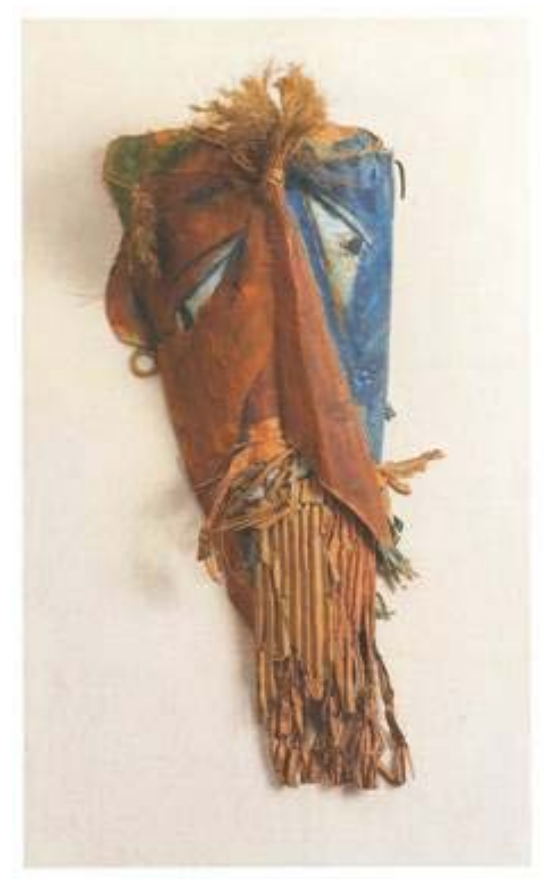

Figure 3.1. Marcel Janco, Untitled (Mask for Firdusi), 1917-1918. From Leah Dickerman. Dada. New York: National Gallery of Art, Washington, 2005, 50.

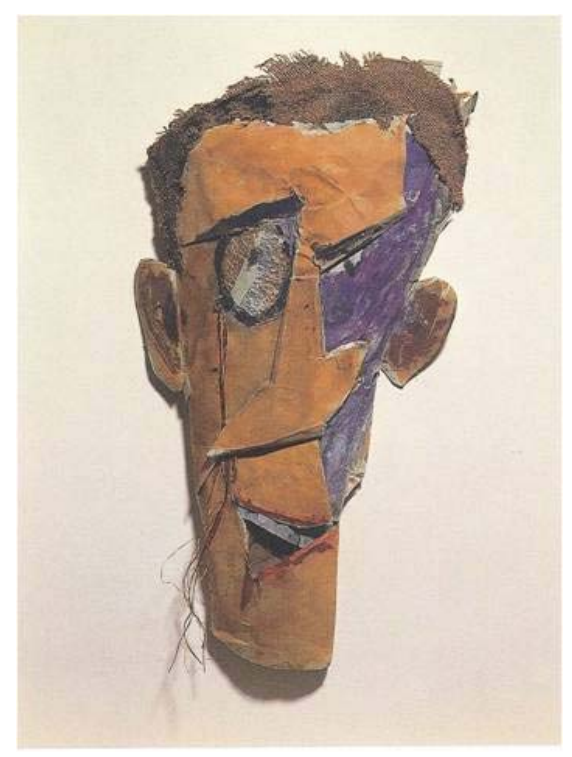

Figure 3.2. Marcel Janco, Untitled (Mask, Portrait of Tzara), 1919. From Leah Dickerman. Dada. New York: National Gallery of Art, Washington, 2005, 51. 


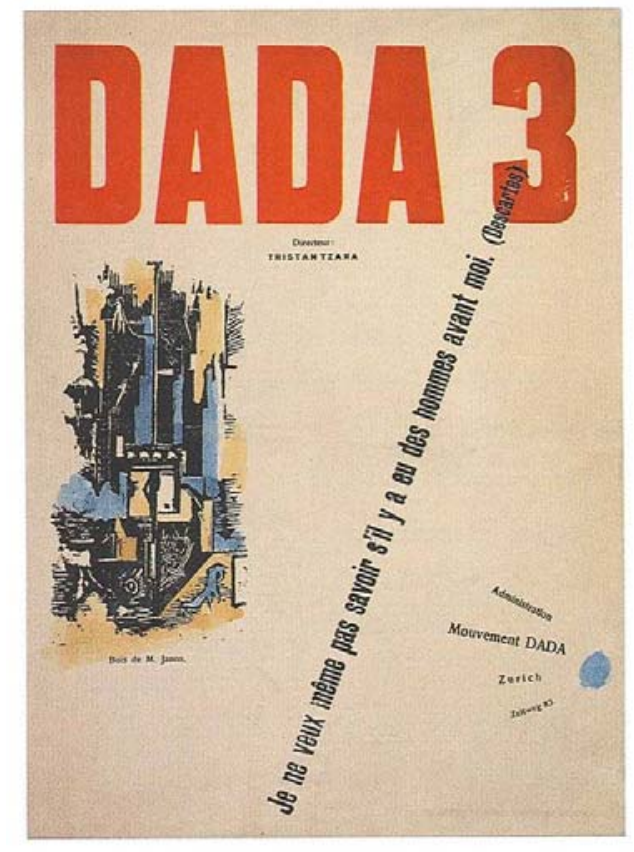

Figure 3.3. Marcel Janco, Illustration of the cover of the journal Dada, no. 3, Tristan Tzara editor, Mouvement Dada, 1918. From Leah Dickerman. Dada. New York: National Gallery of Art, Washington, 2005, 52.
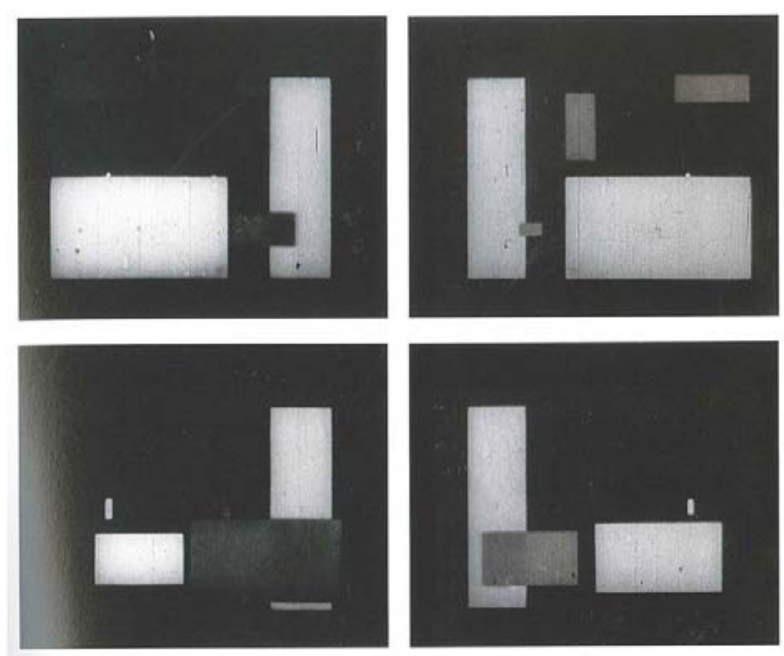

Figure 3.4. Hans Richter, Rhythmus 21 (Rhythm 21), ca. 1921. From Dada: Themes and Movements. Edited by Rudolf Kuenzli. London: Phaidon Press Limited, 2006, 67. 


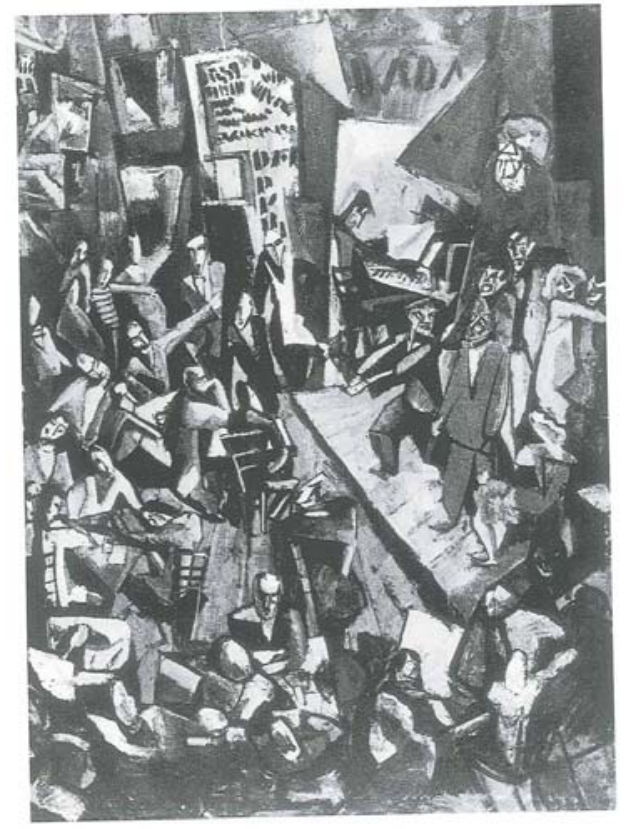

Figure 3.5. Marcel Janco, Cabaret Voltaire, 1916. From Leah Dickerman. Dada. New York: National Gallery of Art, Washington, 2005, 24.

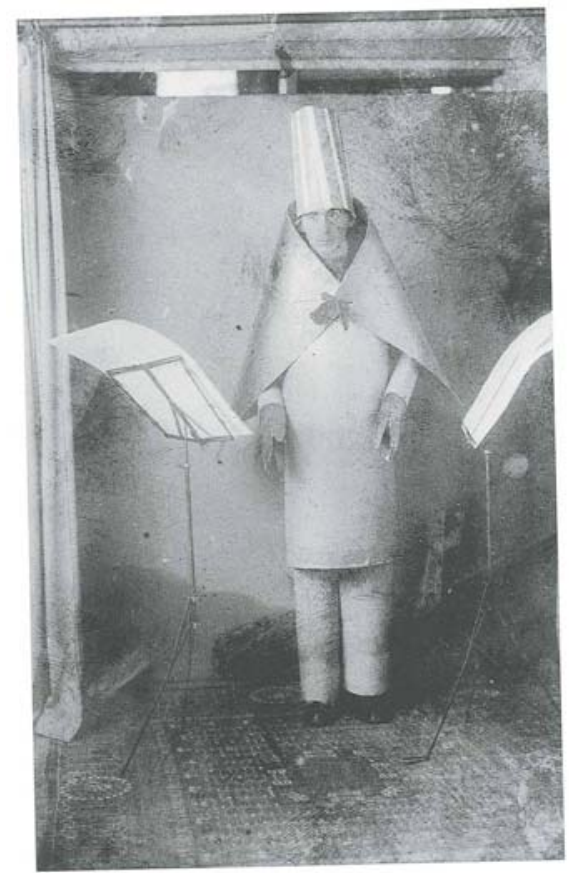

Figure 3.6. Hugo Ball in "cubist costume" reciting his poem Elefantenkarawane, at the Cabaret Voltaire, 23 June 1916. From Leah Dickerman. Dada. New York: National Gallery of Art, Washington, 2005, 28. 


\section{KARAWANE}

jolifanto bambla $\hat{0}$ falli bambla

grossiga m'pfa habla horem

égiga goramen

higo bloiko russula huju

hollaka hollala

anlogo bung

blago bung

blago bung

bosso fataka

\section{iี iี}

schampa wulla wussa ólobo

hej tatta gôrem

eschige zunbada

wulubu ssubudu uluw ssubudu

tumba ba- umf

kusagauma

ba - umf

Figure 3.7. Hugo Ball, Karawane. Sound poem in Dada Almanach, 1920, p.53. From The International Dada Archive of The University of Iowa Libraries.

http://sdrc.lib.uiowa.edu/dada/da/pages/053.html.

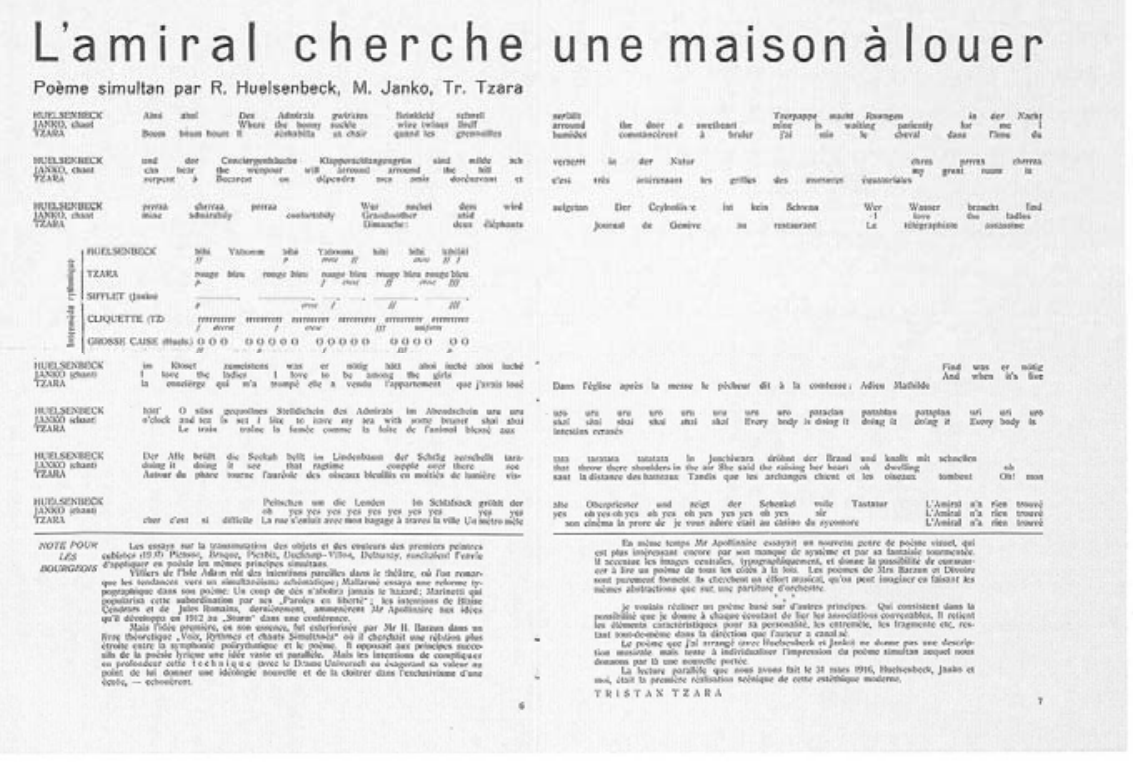

Figure 3.8. Tristan Tzara, L'amiral cherche une maison à louer, as published in the journal Cabaret Voltaire, 1916. From Leah Dickerman. Dada. New York: National Gallery of Art, Washington, 2005, 27. 


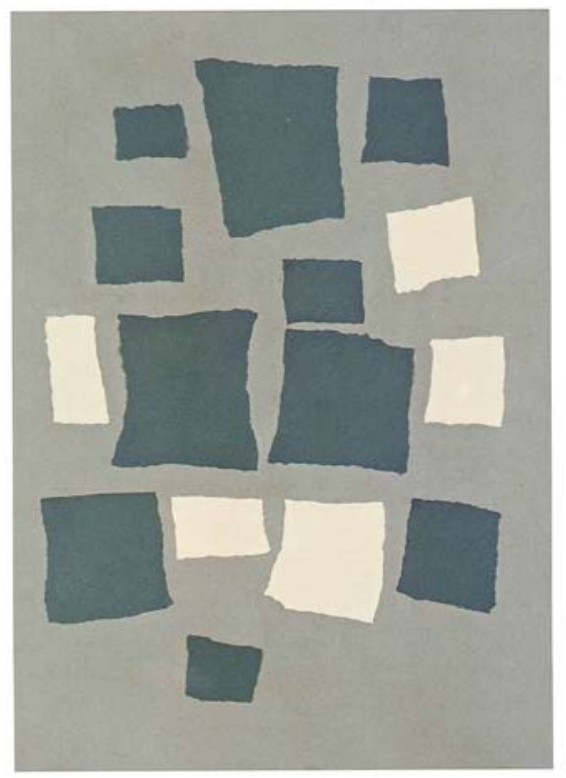

Figure 3.9. Hans Arp, Untitled (Collage with Square Arranged According to the Laws of Chance), 1916-17. From Leah Dickerman. Dada. New York: National Gallery of Art, Washington, 2005, 56.

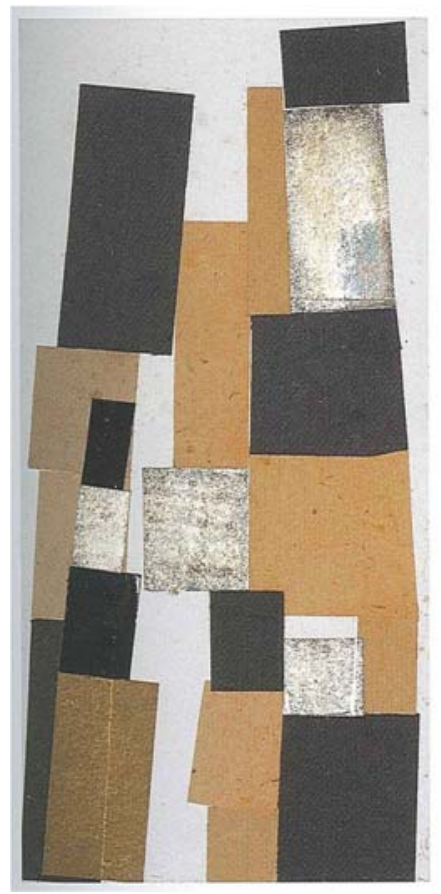

Figure 3.10. Hans Arp, Untitled (Rectangles According to the Laws of Chance), 1916. From Leah Dickerman. Dada. New York: National Gallery of Art, Washington, 2005, 57. 


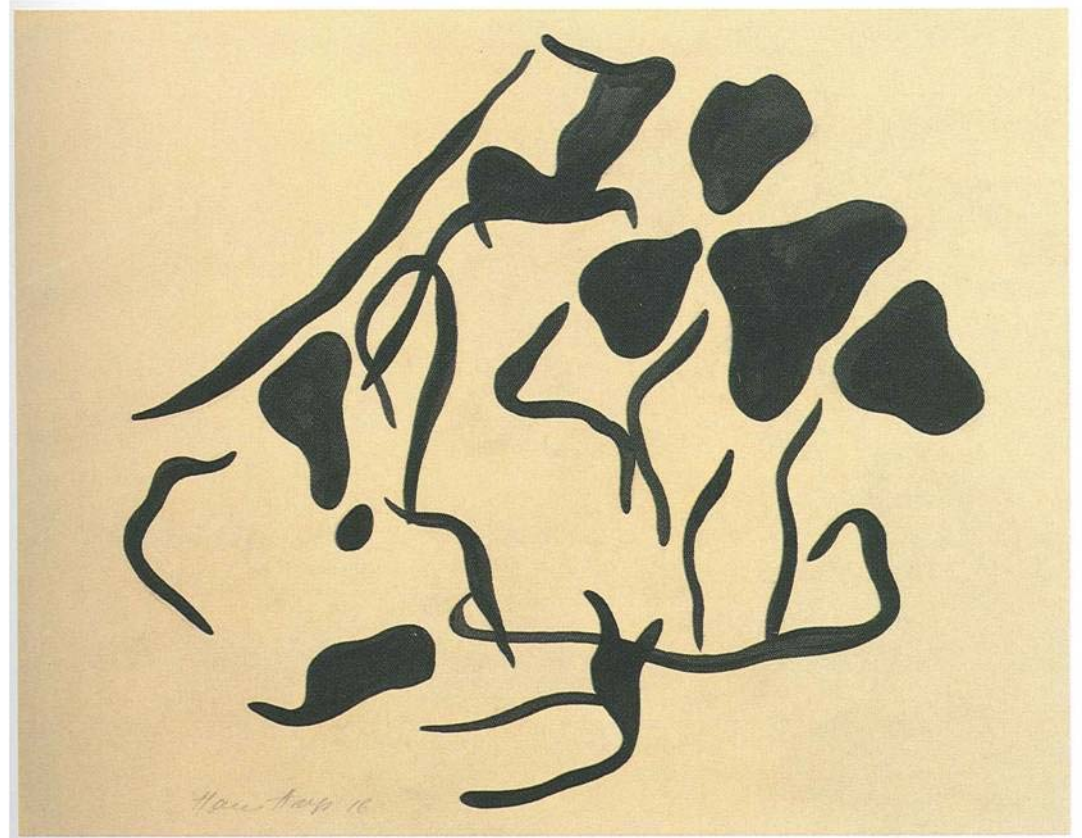

Figure 3.11. Hans Arp, Untitled (Automatic Drawing), 1917-18 (inscribed 1916). From Leah Dickerman. Dada. New York: National Gallery of Art, Washington, 2005, 65. 
Section Four: Conclusion

The Zurich Dadaists evidently had knowledge of different forms of Eastern thought. This is not to say that they directly followed all aspects Taoist or Zen philosophy. Obviously they were not Taoist sages, Buddhist monks, or Zen masters, but one does not have to achieve this level of awareness to find value, worth, or truth in Taoism or Zen. The Dadaists were attracted to a mode of thought that was completely alien to the standard Western mindset and the artists recognized the similarity to their own perspective on existence. William Barrett points out,

That Western painters and sculptors in this century have gone outside their tradition to nourish themselves with the art of the rest of the world - Oriental, African, Melanesian — signifies that what we knew as the tradition is no longer able to nourish its most creative members; its confining mould has broken, under pressures from within. ${ }^{96}$

There was a lack in the Dada artists' own cultural institutions, so they had to look elsewhere to find creative encouragement. What is interesting is that when "the tradition" could no longer sustain the artists of that time, a different tradition did not rise to the top of the artistic hierarchy. Western artists simply borrowed from other cultures and interpreted features in their own way thereby reshaping and refocusing Western art practices. As discussed at the beginning of this paper, Edward Said's theory of Orientalism demonstrates that this type of cultural appropriation is not a new practice in the West. This issue should not be ignored because it only lends further credence to the notion that Zurich Dadaists did have an interest in and were influenced by Eastern thought.

\footnotetext{
${ }^{96}$ Barrett, xiii-xiv.
} 
Various examples have been provided which attest to the affinity Zurich Dada with Taoist and Zen philosophy. Richard Hülsenbeck made statements in which the term Dada was interchangeable with Buddhism, Nirvana, the Tao, and Brahma. Hans Richter spoke about a freedom from the constrictions of conventions and embracing the notion of the unknown while in Zurich. Marcel Janco encouraged childlike thinking since this kind of fresh perspective is unobstructed by established customs and traditions. Hans Arp created art that employed the use of chance and spontaneity. Tristan Tzara's 1918 manifesto alone contains numerous features that correspond to Taoism and Zen: Tzara welcomed contradictions as a way of undermining the traditional mode of thought; accepted the dualistic nature of life and the unity of all aspects of life; questioned the established, rigid classifications of reality; and objected to extreme rationalism which had led to the irrational actions and ideas the Dadaists were encountering during this time in history. Finally, all the Zurich Dadaists shared a distrust for language in its conventional form.

Rudolf Kuenzli relates an interesting account regarding Japanese Dadaists which unites the topics of Dada, Buddhism, and nihilism even further:

In December 1922, Tsuji [Jun] collaborated with Takahashi [Shinkichi] on a conference entitled 'Dada Expression' in Tokyo. Tsuji was scheduled to speak on Dada, Takebayashi Musoan on Buddhism and Oizumi Kokuseki on nihilism; a fight with a taxi driver lead to Takahashi's arrest, and the conference was cancelled. $^{97}$

How fascinating and illuminating it would be to know what was going to be said at that conference. Unfortunately, any documentation of the speakers' thoughts is nonexistent or currently inaccessible. There are obviously more than just parallels between the topics of

\footnotetext{
${ }^{97}$ Kuenzli, 38.
} 
Dada, Buddhism (and Taoism), and nihilism. Dada and Eastern thought share a certain mindset. A comparison of the two emphasizes the lack of nihilism in Buddhism and Taoism and encourages a reconsideration of further labeling Dada "as a nihilistic enterprise." 98

After much research, only one author can be found that directly denies Dada's characterization as nihilistic and anarchic, other than the artists themselves. Allan C. Greenberg states,

The Dadaists did not deny reality, but affirmed both it, as they interpreted it, with its crassest features, and the elements by means of which one might transcend reality. In the very limited sense of denying previous systems and values they might be considered nihilists, but even here there was no explicit (or implicit) denial of all preceding systems and values: freedom and individualism were not Dadaists inventions. And they did not deny art, but only the art as then practiced. ${ }^{99}$

Dada artists may have been rebelling against the current construction of reality that they found themselves situated within, but this does not equate to a rejection of existence as a whole. As Greenberg points out, this extends to their conception of art as well.

Dada creations are not anti-art or non art. The art that Dadaists produced was a reaction against the established artistic tradition that was losing its relevance and status in an ever modernizing world. As such, Dada art is actually continuing the story of the history of art while changing the plot of that story by redirecting the focus of the art world. Dada was participating in a dialogue with the tradition of art and is now part of art history itself. Thus, it is absurd to think that Dada is against art or nihilistic. If Dada saw no meaning in life, no value, or no purpose, why would they expend such an extraneous effort on creating art that required a re-conception of the notion of art in general? This is

\footnotetext{
${ }^{98}$ Gardner's, 198.

${ }^{99}$ Greenberg, 115.
} 
quite an undertaking, which demonstrates a commitment to art and is counter to the very notion of nihilism.

The question remains, then, if one can counter the claim of nihilism that is always applied to Dada, is it appropriate to continue to include this feature in discussions about Dada as it is currently understood. Since the ways in which Dada manifested itself across Europe and the United States differs to a certain degree, the issue of nihilism may be more relevant depending on the "type" of Dada. If it is the case that the practices of some Dada artists can be considered nihilistic and their actions have no affinity with the ideas surrounding Eastern thought, then should certain factions of Dada, such as the individuals mentioned in the Zurich group, be discussed separately, as an anomaly, or as a unique, "original" form of the avant-garde movement? Dada's vague character actually allows for copious materializations of the movement, so distinctions between different Dada groups may not be problematic. However, since there is a tendency to generalize artistic practices into concise, consecutive -isms, there is always a chance that certain qualities of the Zurich Dadaists are likely to be ignored and broad traits will continue to be applied to them in an indiscriminant manner. This paper has attempted to challenge that tendency and encourage open perspectives which will allow for an enhanced understanding of Dada. 


\section{Bibliography}

Berard, T.J. "Dada between Nietzsche's Birth of Tragedy and Bourdieu's Distinction: Existenz and Conflict in Cultural Analysis." Theory, Culture \& Society 16, no. 1 (1999): http://tcs.sagepub.com/cgi/content/abstract/16/1/141.

Dada: Themes and Movements, edited by Rudolf Kuenzli. London: Phaidon Press Limited, 2006.

Dickerman, Leah. Dada. New York: National Gallery of Art, Washington, 2005.

Droit, Roger-Pol. The Cult of Nothingness: The Philosophers and the Buddha, translated by David Streight and Pamela Vohnson. Chapel Hill: University of North Carolina Press, 2003.

Froes, Katrin. Nietzsche, Heidegger, and Daoist Thought: Crossing Paths In-Between. Albany: State University of New York Press, 2006.

Greenberg, Allan C. Artists and Revolution: Dada and the Bauhaus, 1917-1925. Ann Arbor, Michigan: UMI Research Press, 1979.

Hülsenbeck, Richard. "Dada Forward.” In Dadas on Art, edited Lucy R. Lippard. Englewood Cliffs, NJ: Prentice-Hall, 1971.

Hülsenbeck, Richard. "Invest in Dada!” In Dadas on Art, edited by Lucy R. Lippard. Englewood Cliffs, NJ: Prentice-Hall, 1971.

Janco, Marcel. "Dada at Two Speeds.” In Dadas on Art, edited by Lucy R. Lippard. Englewood Cliffs, NJ: Prentice-Hall, 1971.

Morrison, Robert G. Nietzsche and Buddhism: A Study in Nihilism and Ironic Affinities. Oxford: Oxford University Press, 1997.

Omuka, Toshiharu. "Tada=Dada (Devotedly Dada) for the Stage: The Japanese Dada Movement." In The Eastern Dada Orbit: Russia, Georgia, Ukraine, Central Europe and Japan, edited by Stephen C. Foster. New York: G.K. Hall \& Co., 1998.

Peterson, Elmer. Tristan Tzara: Dada and Surrational Theorist. New Brunswick, New Jersey: Rutgers University Press, 1971.

Primitivism and Twentieth-Century Art: A Documentary History, edited by Jack Flam with Miriam Deutch. Berkeley: University of California Press, 2003.

Richter, Hans. Dada: Art and Anti-art. New York: Harry N. Abrams, Inc., 1964. 
Said, Edward. Orientalism. New York: Vintage Books, 1979.

Sheppard, Richard. Modernism-Dada-Postmodernism. Evanston, Illinois: Northwestern University Press, 2000.

Smullyan, Raymond M. The Tao is Silent. San Francisco: Harper Collins, 1977.

Tzara, Tristan. "Dada Manifesto." In Between Worlds: A Sourcebook of Central European Avant-gardes, 1910-1930, edited by Timothy O. Benson and Éva Forgács. Los Angeles: Los Angeles County Museum of Art, 2002.

Vlasiu, Ioana. "Bucharest." In Central European Avant-gardes: Exchange and Transformation, 1920-1930, edited by Timothy O. Benson. Los Angeles: Los Angeles County Museum of Art, 2002.

Watts, Alan. The Way of Zen. New York: Vintage Books, 1957.

Watts, Harriett Ann. Chance: A Perspective on Dada. Ann Arbor, MI: UMI Research Press, 1980.

Won, Ko. Buddhist Elements in Dada: A Comparison of Tristan Tzara, Takahashi Shinkichi, and Their Fellow Poets. New York: NYU Press, 1977.

Zen Buddhism: Selected Writings of D.T. Suzuki, edited by William Barrett. New York: Three Leaves Press, 2006. 
Author's Name - Erin Megan Lochmann

Birthplace - Pensacola, Florida

Birth Date - June 12, 1984

\section{Education}

Bachelors of Art in Art History, graduated Cum Laude

Middle Tennessee State University

May 2008

\section{Professional Experience}

University of Kentucky

Lexington, $\mathrm{KY}$

August 2008 - May 2009

Curatorial Internship at the Art Museum and the Tuska Center for Contemporary Art

University of Kentucky

Lexington, KY

May 2009 - Present

Curatorial Assistant and May Lecture Series Coordinator at the Art Museum 